Acta Biologica Plantarum Agriensis 5(1): 32 (2017)

ISSN 2061-6716 (Print), 2063-6725 (Online)

DOI:10.21406/abpa.2017.5.1.32

http://abpa.ektf.hu/

$4^{\text {th }}$ CC Abstact

Lecture

\title{
DISTRIBUTION AND HABITAT PREFERENCE OF BUXBAUMIA HEDW. SPECIES IN HUNGARY
}

A magyarországi Buxbaumia Hedw. fajok elterjedése és élőhelyi preferenciája

Judit DEME ${ }^{1}$, Peter ERZBERGER², Dániel KovÁCS ${ }^{3}$, Kornél BARÁTH ${ }^{4}$, István

LANTOS $^{5}$, Gábor MAGOS ${ }^{5}$, József NAGY ${ }^{6}$, Katalin NAGY ${ }^{1}$, Zoltán NAGY ${ }^{7}$, Csaba

NÉMETH $^{8}$, Péter ÓDOR ${ }^{9}$, Beáta PAPP ${ }^{10}$, István Zsolt TóTH ${ }^{11}$ \& János CSIKY ${ }^{1}$

${ }^{1}$ University of Pécs, Faculty of Sciences, Institute of Biology, Department of Ecology; ${ }^{2} \mathrm{D}-$ 10823 Berlin, Belziger Str. 37, Germany; ${ }^{3} \mathrm{H}-2422$ Mezőfalva, Fehérvári út 41., Hungary; ${ }^{4}$ Department of Biology, Savaria Campus, Eötvös Loránd University; ${ }^{5}$ Bükk National Park

Directorate; ${ }^{6}$ Szent István University, Faculty of Horticultural Science, Department of Botany; ${ }^{7}$ Cereal Research Non-profit Ltd.; ${ }^{8}$ MTA Centre for Ecological Research, Institute of Ecology and Botany, GINOP Sustainable Ecosystems Group; ${ }^{9}$ MTA Centre for Ecological Research, Institute of Ecology and Botany; ${ }^{10}$ Hungarian Natural History Museum; ${ }^{11}$ Duna-Dráva National Park Directorate; e-mail: hiddenit92@gmail.com

The genus Buxbaumia includes two species (B. aphylla and B. viridis) in Hungary. Both of them were thought to be rare and threatened: $B$. aphylla was rated as Vulnerable (VU), while B. viridis as Endangered (EN) on the national Red List. The latter is a Natura 2000 species and protected by law in the country.

The aims of the research were to summarize the historical and actual distribution of these taxa and to reveal their habitat preference, population size and phenology in Hungary. During systematic surveys from 2014 to 2017, we have checked previously known localities and similar habitats in several Hungarian landscapes. In almost every newly discovered stand, phytocoenological relevés were taken in $1 \mathrm{~m}^{2}$ plots. We recorded here the number, state and maximal density (plant/1 $\mathrm{dm}^{2}$ ) of the individuals (sporophytes or setae), and listed the presence of cooccurring species. The cover values of moss layer, bare surfaces and organic debris were estimated; the exposure and the inclination were measured.

We have found some formerly known and many more newly discovered populations of Buxbaumia species. Although B. viridis is usually considered to be an epixylic bryophyte, both species occurred mostly on soil, on steep, north-facing slopes, in stands of acidophilous communities. However, B. aphylla was more common in drier acidophytic oak forests, while $B$. viridis preferred acidophytic beech forests. In both cases, the most frequent (fr. $\geq 50 \%$ ) co-occurring mosses were Dicranella heteromalla, Dicranum scoparium, Hypnum cupressiforme and Polytrichum formosum. According to the observed habitat preference and using MÉTA maps, we presume further potential occurrences of shield-mosses in Hungary, mainly in hilly regions. Since more than 1600 individuals and 160 (usually stable) stands of both taxa were discovered recently in the country, we suggest that their threat status should be lowered to Near Threatened (NT) in the next Bryophyte Red List of Hungary. Whereas the characteristics of B. aphylla are similar to those reported in the literature, our results on the habitat preference of $B$. viridis greatly differ from the Hungarian and international published accounts. Our new observations will be relevant for the protection of $B$. viridis in the future. 